\title{
分子軌道計算によるリチウムリン酸塩ガラス中の酸素の局所構造と 電子状態の評価
}

\author{
瀬川浩代 ·矢野哲司・柴田修一・山根正之 \\ 東京工業大学工学部無機材料工学科, 152-8552 東京都目黒区大岡山 2-12-1
}

\section{Local Structure and Electronic State of Oxygens in Lithium Phosphate Glasses Calculated by Molecular Orbital Theory}

\author{
Hiroyo SEGAWA, Tetsuji YANO, Shuichi SHIBATA and Masayuki YAMANE \\ Department of Inorganic Materials, Faculty of Engineering, Tokyo Institute of Technology, 2-12-1, Ookayama, Meguro-ku, Tokyo $152-8552$
}

\begin{abstract}
The validity of separating $01 \mathrm{~s}$ photoelectron spectra of alkaline phosphate glasses into three peaks assigned to bridging, non-bridging and double-bonded oxygen atoms was discussed on the basis of the molecular orbital calculations by density functional method. Models used for the calculations were lithium metaphosphate chain clusters consisting of 2,4 and $5 \mathrm{PO}_{4}$ units. Two oxygen atoms around a $\mathrm{Li}^{+}$ion, nonbridging oxygen and double-bonded oxygen, were structurally indistinguishable, and were considered to be classified into the same terminal atoms. The $01 \mathrm{~s}$ orbital energies of these terminal oxygen atoms were consistent to each other within $0.4 \mathrm{eV}$. The variation in orbital energies probably results from inhomogeneous broadening caused by the statistically distributed surroundings around $\mathrm{PO}_{4}$ units. From these results, it was concluded that in 01s photoelectron spectra of phosphate glasses, the separation of the lower binding energy side peak into two bands is not appropriate. [Received May 10, 1999; Accepted August 23, 1999]
\end{abstract}

Key-words : O1s photoelectron spectra, Electronic state, Lithium phosphate, Molecular orbital calculation

\section{1. 緒 論}

酸化物ガラスの酸素の電子状態は酸素原子の周囲の化学結合 の違いを反映して変化する．この酸素の電子状態の違いが， ドーパントとしてガラスに添加した Fe などの多原子価イオン の価数変化に大きな影響を与えることが知られており，酸素の 電子状態を定量的に表すことができるならば，それはガラスの 塩基度を評価するための有効なパラメーターになると考えられ る.

ガラス構造を形成している酸素の電子状態は X 線光電子分 光（XPS）を用いることによって直接的に測定できる．例え ば, ケイ酸塩ガラスでは, 酸素の内殼 $1 \mathrm{~s}(\mathrm{O} 1 \mathrm{~s})$ 軌道の光電子 スペクトルとして二つの異なるピークが測定され，高エネル ギー側のピークが架橋酸素, 低エネルギー側が非架橋酸素に帰 属されており, そのエネルギー差は約 $2 \mathrm{eV}$ 程度になってい る1),2)。松本らは, 測定法を確立することにより O1s 結合エネ ルギーが，ガラスを構成する網目修飾酸化物の量比, 種類に よってケミカルシフトを起こすことを示しており2，01s 結合 エネルギーの測定により, 酸素の電子状態を定量的に表すこと ができることが示唆されている.しかし，ホウ酸塩ガラスの O1s 光電子スペクトルは，ケイ酸塩ガラスのような明瞭に分か れた二つのピークではなく，一つのブロードなピークとして観 測されている3)。 また，リン酸塩ガラスではリンが 5 価で 4 配 位構造を取るために化学的には架橋酸素と非架橋酸素のほかに 二重結合酸素も存在すると考えられるが, 実測されたアルカリ リン酸塩ガラスの $01 \mathrm{~s}$ 光電子スペクトルにおいては, 二つの ピークが見られるのみである1),4) 6).

リン酸塩ガラスの酸素の化学結合状態に関しては, 赤外分光 法による解析も可能である. Hudgens と Martinは, $\mathrm{Li}_{2} \mathrm{O}-$ $\mathrm{P}_{2} \mathrm{O}_{5}$ 系ガラスの $\mathrm{Li}_{2} \mathrm{O}$ を 0 50 mol\%の範囲で変えながら赤外 吸収を測定し, リンと酸素の化学結合状態の変化について報告 した7). 彼らはガラス中の二重結合, $\mathrm{P}=\mathrm{O} の \pi$ 電子が, $\mathrm{Li}_{2} \mathrm{O}$ の増加に伴い, 新しく生成する非架橋酸素との間に分布し, 共
鳴状態になると結論づけている.

前述した $01 \mathrm{~s}$ 光電子スペクトルについて, 高エネルギー側 のピークは架橋酸素に帰属されているが, 低エネルギー側の ピークに関しては異なった二つの扱いがなされている. Gresch ら")及び Kaneko5) は, 赤外吸収における Hudgens らと同様 に, 非架橋酸素と二重結合酸素が共鳴状態を取っており, 一つ のピークに帰属できるものとして解釈している. 一方, Brückner $ら^{1)}$ は, ガラスの組成から架橋酸素, 非架橋酸素, 二重結 合酸素の量比を計算して, 低エネルギー側のピークを非架橋酸 素々二重結合酸素の 2 種類の酸素に㷌属し, 更に計算上では, 非架橋酸素々二重結合酸素の量比が同じであるメタ組成の場合 においても，これらの酸素の結合エネルギーは約 $0.4 \mathrm{eV}$ 異 なった，区別できるものであることを報告している.

これまでの報告例8) 14) から考えると, 化学結合状態と電子 状態の検討には分子軌道計算が有効な手段となりうると考えら れる. 分子軌道計算では電子間の相互作用を取り入れることが でき, 各軌道のエネルギーを計算することによって, 結合エネ ルギーを予測することが可能である. Uchino と Ogataは, ア ルカリリン酸塩ガラスに関して分子軌道計算を適用し, 計算で 得られたデータと各種分光法での実測值との対応関係が得られ ることを報告して抢り，XPSに関しても O 1s 軌道エネルギー と $01 \mathrm{~s}$ 光電子スペクトルとの対応関係を確認している 彼らは, $\mathrm{Na}_{2} \mathrm{O}-\mathrm{P}_{2} \mathrm{O}_{5}$ 系ガラスに関する $\mathrm{O} 1 \mathrm{~s}$ 光電子スペクトル の二重結合酸素と非架橋酸素の解釈について O1s 軌道エネル ギーを用いて記述しており， $\mathrm{PO}_{4}$ 四面体 2 個からなる小さな クラスターを用いた計算結果から, これらの酸素を明らかに区 別するような構造的な違いは存在せず, その $01 \mathrm{~s}$ 軌道エネル ギーの差も $0.02 \mathrm{eV}$ と非常に小さいことを示している14). しか しながら, 実際のガラス中に存在するような不規則性に伴って どのように酸素の電子状態に影響を及ぼすかに関しては記述さ れておらず，また，メタ組成における Brückner ら1)のピーク 分離結果で得られた約 $0.4 \mathrm{eV}$ のエネルギー差との相違に関し 
ての議論はなされていない.

本論文では，O1s 光電子スペクトルの低エネルギー側のピー クを非架橋酸素と二重結合酸素に分けて帰属すべきか，または 共鳴状態として本来一つのピークとして解釈すべきかをガラス 中の不規則構造を配慮した分子軌道計算を行うことによって検 討を行った。

\section{2. モデルと計算方法}

分子軌道計算においては，用いるモデルがぞの程度実際の系 を反映しているかが重要である．これらの酸素の状態がどのよ うになっているのかを明確にするために，本論文では同組成の 結晶が存在するリチウムメタリン酸塩を取り上げる.リチウム メタリン酸塩は，結晶とガラスに関してラマンスペクトルが測 定されており，どちらも鎖状構造を有していることが確認され ている15).ガラスが結晶の構造16),17) と類似していることが明 らかになっているこの組成においては, 結晶構造から推定する 々，構造的に非架橋酸素之二重結合酸素の区別がない共鳴状態 であると考えられる.

このような構造を有するモデルとしては, リチウムと酸素の 間の結合状態において次のようなものが考えられる. 同じ鎖上 にある異なる酸素が $\mathrm{Li}^{+}$イオンと共鳴状態を取っている場合 及び別の鎖上にある異なる酸素が $\mathrm{Li}^{+}$イオンと共鳴状態を 取っている場合である．同じ鎖上での共鳴状態では，1個の $\mathrm{PO}_{4}$ 四面体ユニット内で共鳴状態になっているものと同じ鎖 上にある異なる $\mathrm{PO}_{4}$ ユニット間で共鳴状態になっているもの が考えられる，本論文中に抢いては， $\mathrm{PO}_{4}$ ユニット 2 個とい う小さいサイズのモデルでもその電子状態を検討することがで き，またそれぞれの $\mathrm{PO}_{4}$ エニットをつなぎ合わせていくこと で長鎖状の構造を容易に作ることができるという理由から，1 個の $\mathrm{PO}_{4}$ 四面体ユニット内で共鳴状態になっている構造を取 り上げる、計算では, 非架橋酸素と二重結合酸素の区別を検討 する必要性から, 分子軌道計算を行う際の初期の構造において これらの酸素を区別し， 1 個の $\mathrm{PO}_{4}$ のユニット中に $\mathrm{Li}^{+}$イオ ンに結合した非架橋酸素及び $\mathrm{Li}^{+}$イオンには結合していない 二重結合酸素をそれぞれ 1 個ずつ含むモデルを用いた。

実際にはリチウムリン酸塩鎖状構造を形成する $\mathrm{PO}_{4}$ 四面体 ユニット間の結合位置の変化により, 非架橋酸素, 二重結合酸 素がどのような影響を受けるかを調べるために $\mathrm{PO}_{4}$ ユニット 2 個のモデルを取り上げた．更に， $\mathrm{PO}_{4}$ ユニットの個数を 2 , 4, 5 個と増やしたモデルによる鎖長依存性の検討, 5 ユニット 鎖を用いた二面角依存性の検討を行った.

まず，隣接する二つの $\mathrm{PO}_{4}$ ユニットの結合位置の変化に 伴って, 各ユニットに対して一つずつ割り当てた $\mathrm{Li}^{+}$イオン がぞのような結合状態を形成するかについて， $\mathrm{PO}_{4}$ ユニット を 2 個含む $\mathrm{P}_{2} \mathrm{O}_{7} \mathrm{Li}_{2} \mathrm{H}_{2}$ モデルを用いて検討した. 計算に用い た 4 通りのモデルを図 1 に示す。これらのモデル中の水素は 擬原子として酸素のダングリングボンドを終端するために用い た. (a)Li2-a モデルは，低温型 $\mathrm{LiPO}_{3}$ 結晶16),17)における $\mathrm{PO}_{4}$ ユニットの位置関係と同様でめり, $\mathrm{O} 2=\mathrm{P} 1-\mathrm{O} 1-\mathrm{P}^{\prime}=\mathrm{O} 22^{\prime}$ を 同一平面上に束縛した。このモデルをもとにして，図 1(a)に 示すように，中央の-P1-01-P1'-について $\mathrm{P} 1-01$ 軸を中心に して $\mathrm{P} 1^{\prime}$ を含む-P1'(O2') (O3'Li1') $\mathrm{OH}$ ユニットを回転させる ことで他のモデルとした（b)Li2-bモデルは Li1-P1-O1$\mathrm{P}^{\prime}-\mathrm{Li1}$ 'が同一平面上になるように回転させたモデルとした. (c)Li2-c モデルは更に回転させた状態を示し, P1-O1-P1' 平 面に対して二重結合になっている酸素 $\mathrm{O} 2, \mathrm{O} 22^{\prime}$ が上下に垂直に 飛び出している. (d)Li2-d モデルは（H-)O4-P1-O1-P1'-
O4'(-H) が同一平面上になるように束縛した。これらのモデ ルを初期構造とした構造最適化では, 両側の $\mathrm{PO}_{4}$ ユニットが 中央の酸素 $\mathrm{O} 1$ を中心として構造的に等しくなるように結合距 離及び結合角に束縛を与えるとともに，Li2-b 以外のモデルに

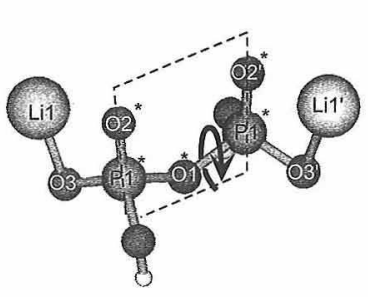

(a)

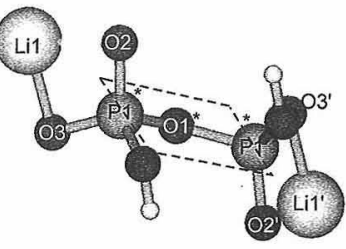

(c)

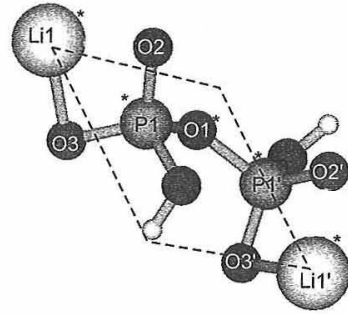

(b)

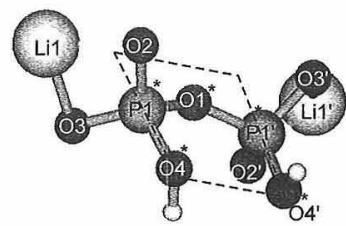

(d)
Fig. 1. Calculated cluster models containing two $\mathrm{PO}_{4}$ units; (a) Li2-a model, (b) Li2-b model, (c) Li2-c model and (d) Li2-d model. These $\mathrm{Li} 2-\mathrm{b}, \mathrm{Li} 2-\mathrm{c}$ and $\mathrm{Li}$ - $\mathrm{d}$ models were formed by the rotation of the unit containing $\mathrm{P1}^{\prime}$ atom in the direction of the arrow shown in (a). The atoms with $\left(^{*}\right)$ were restricted in a plane shown by broken line at the optimization procedure.

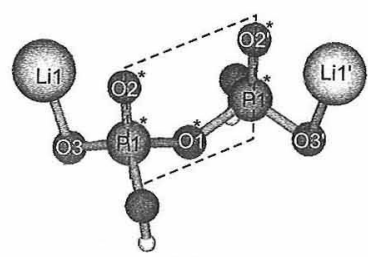

(a)
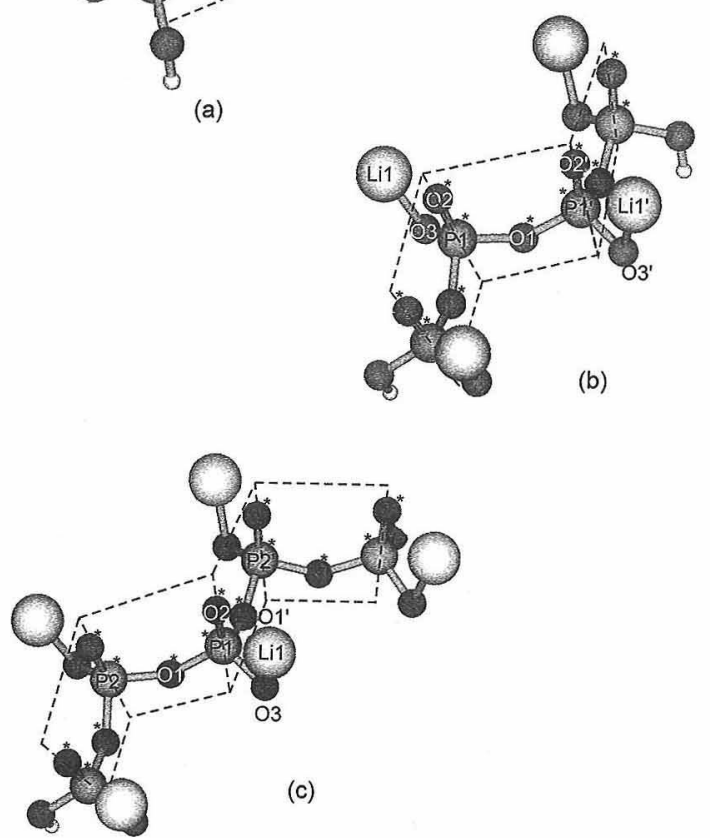

Fig. 2. Calculated cluster models containing different number of $\mathrm{PO}_{4}$ units ; (a) Li2-a model (see in Fig. 1), (b) Li4 model and (c) Li5 model. The atoms with $\left(^{*}\right)$ were restricted in planes shown by broken line at the optimization procedure. 
おいては架橋酸素 $\mathrm{O} 1$ に対して C2 対称を仮定した。系統的に $\mathrm{PO}_{4}$ ユニットの位置を変化させてあるため, $\mathrm{PO}_{4}$ ユニット間 のねじれ配置が最適化後の構造に与える影響を明らかにするこ とができる。

次に $\mathrm{PO}_{4}$ ユニット数を大きくし，鎖長依存性について検討 した．それぞれのモデルを図 2 に示す． $\mathrm{PO}_{4}$ ユニットを 2 個 含むモデルとしては Li2-a モデルを用い，終端している H を $\mathrm{PO}_{4}$ ユニットに置き換えることによって鎖長をのばした. 4 個 の $\mathrm{PO}_{4}$ を含む $\mathrm{Li} 4$ モデルでは, 低温型 $\mathrm{LiPO}_{3}$ 結晶中の四面体 の位置関係 ${ }^{16)}$,17) に基づいて，隣り合った 2 個の $\mathrm{PO}_{4}$ ユニット 間の $\mathrm{O} 2=\mathrm{P} 1-\mathrm{O} 1-\mathrm{P}^{\prime}=\mathrm{O}^{\prime}$ は同一平面上にあるように束縛し た.このとき, 中心の酸素 01 に対して C2 対称を仮定した. 更に 5 個の $\mathrm{PO}_{4}$ ユニットを含む Li5 モデルでは Li4 モデルの 最適化構造の中心部に $\mathrm{PO}_{4}$ ユニットを挿入し, 両側の $-\mathrm{P}_{2} \mathrm{O}_{6}$ $\mathrm{Li}_{2} \mathrm{H}$ は $\mathrm{Li} 4$ モデルで最適化された構造をそのまま利用し, 中 央の $\mathrm{LiPO}_{4}$ ユニットのみを最適化した。

最後に, 鎖構造の変化に伴って構造最適化された電子状態が どのように変化するのかを調べるために, 構造最適化された $\mathrm{Li} 5$ モデルを用い，中央の $\mathrm{LiPO}_{4}$ ユニットに含まれる酸素につ いてそれぞれ検討した． $\mathrm{Li} 5$ モデルの中央の $\mathrm{LiPO}_{4}$ エニットと 雨側の $-\mathrm{P}_{2} \mathrm{O}_{6} \mathrm{Li}_{2} \mathrm{H}$ ユニットの間の面角を変化させて鎖構造を 変化させた. 具体的には図 3 に示すように, 中央の -01-P1
(O2) (O3Li1)-O1'ーユニットに対して, 雨側の- $\mathrm{PO}_{2} \mathrm{LiOPO}_{3}$ $\mathrm{LiH}$ を O2-P1-O1 面と P1-O1-P1' 面の 2 面角が $30^{\circ}, 60^{\circ}, 90^{\circ}$ となるように反対方向に回転させた場合（Li5-A グループ，図 3(a)）上， $-60^{\circ},-30^{\circ}, 30^{\circ}, 60^{\circ}$ となるように同一方向に回転 させた場合（Li5-Bグループ, 図 3(b)）について計算を行っ た.これらのモデルに関しては，電子状態を評価することに主 眼をおさ，構造の最適化は行わずに 1 点計算のみで評価した。

計算には，電子密度の関数を用いることによって，短い時間 で電子相関を含んだクラスター計算ができることが知られてい る密度汎関数法 (DFT) ${ }^{18)}$ を用いた，実際の計算はクレイコン ピューター上の Gaussian9419) 党用いて行った。この計算にお いては Lee らの相関沉関数を用いた Becke's three-parameter hybrid method (B3LYP) ${ }^{20)}$ を交換相関沉関数として用いた。

ここで交換相関エネルギー $E_{X C}^{B 3 L Y P}$ は次式で表される.

$$
\begin{aligned}
E_{X C}^{B 3 L Y P}= & \left(1-a_{0}\right) E_{X}^{L S D A}+a_{0} E_{X}^{H F}+a_{X} \Delta E_{X}^{B 88}+a_{\mathrm{C}} E_{C}^{L Y P} \\
& +\left(1-a_{0}\right) E_{C}^{V W N}
\end{aligned}
$$

ここで， $E_{X}^{L S S D A}$ は局所久ピン密度近似 (LSDA) の交換エネル ギーであり， $E_{X}^{H F}$ は実際の (Hatree-Fock) 交換エネルギーで ある。 $E_{C}^{L Y P}$ と $E_{C}^{V W N}$ はそれぞれLee ら ${ }^{21)}$ とVosko ら 22$) に$ よって提案された相関エネルギーで岁る、 $\Delta E_{X}^{B 88}$ は交換関数の 勾配の相関23) を表している. Becke は係数を $a_{0}=0.2, a_{X}=$ $0.72, a_{C}=0.81$ と提案している.
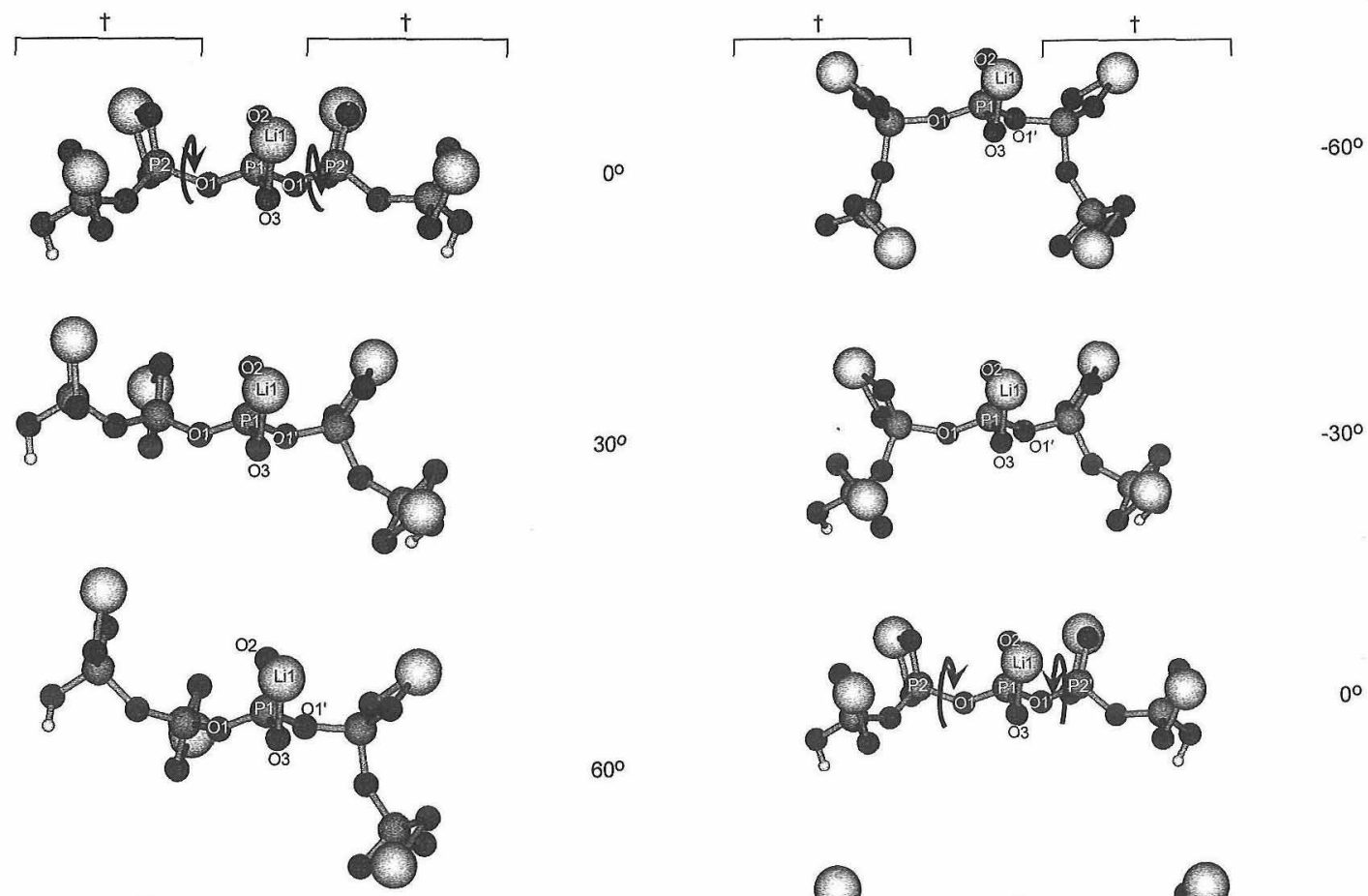

$60^{\circ}$

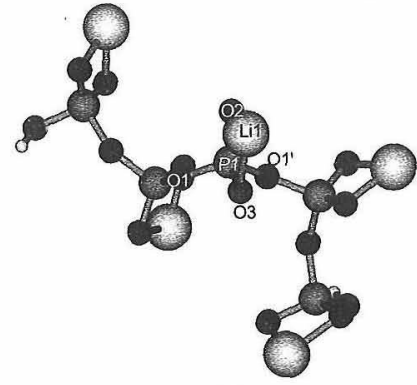

(a)

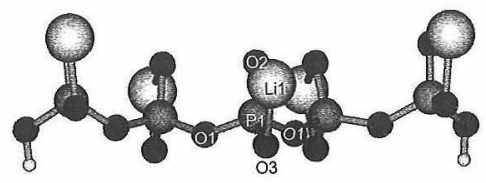

$90^{\circ}$

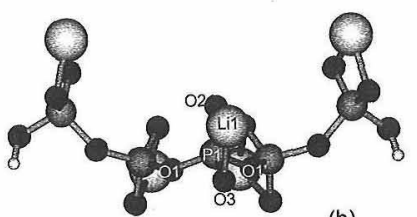

$-30^{\circ}$

$0^{\circ}$

$-60^{\circ}$

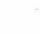

$30^{\circ}$

$60^{\circ}$

Fig. 3. Calculated cluster models containing five $\mathrm{PO}_{4}$ units. The $\mathrm{P}_{2} \mathrm{O}_{5} \mathrm{Li} 2 \mathrm{H}$ units (shown by $\dagger$ ) were taken from the optimized Li4 model. In (a) Li5-A group, two $\mathrm{P}_{2} \mathrm{O}_{5} \mathrm{Li} 2 \mathrm{H}$ units were rotated towards different direction shown by arrows, while, in (b) Li5-B group, they were rotated towards the same direction. 
基底関数としてはダブルゼータ型の $\mathrm{DZVP}^{24)}$ を用いた。こ の関数を用いると, 酸素は $(9 \mathrm{~s}, 5 \mathrm{p}, 1 \mathrm{~d}) /[3 \mathrm{~s}, 2 \mathrm{p}, 1 \mathrm{~d}]$, リンは $(12 \mathrm{~s}, 8 \mathrm{p}, 1 \mathrm{~d}) /[4 \mathrm{~s}, 3 \mathrm{p}, 1 \mathrm{~d}]$, 水素は $(5 \mathrm{~s}) /[2 \mathrm{~s}]$, リチウムは (9s, 1p, 1d)/[3s, 1p, 1d] で表される.

各モデルについて，酸素のマリケン電荷及び $\mathrm{O}$ s 軌道エネ ルギーの計算を行った. 密度沉関数法では電子相関を取り込ん だ関数を用いているため, 計算される軌道エネルギーは, Hatree-Fock 法における Koopmans の定理25)のように，光電 子スペクトルとして測定される結合エネルギーとの直接的な対 応関係を持たない。しかしながら, 密度汎関数法で得られる軌 道エネルギーに対しては, 系の全エネルギーを電子の占有数で 微分した值に等しいという Janak の定理 ${ }^{26)}$ が成り立っており, 注目する原子の電子状態を半定量的に表すことができる，その ため，本計算に抢いては，マリケン電荷と01s 軌道エネル ギーを酸素の電子状態を表す尺度として取り上げた。

\section{3. 結 果}

\section{$3.1 \mathrm{PO}_{4}$ ユニット 2 個のクラスター}

束縛条件を変えたときの局所構造と電子状態の関係を検討す るために計算したモデル Li2-a, Li2-b, Li2-c, Li2-d についての 結果を表 1 に示した．結合距離はモデルによらずほぼ一定の值 を示した. 一方, 結合角 $\angle \mathrm{P} 1-\mathrm{O} 1-\mathrm{P} 1$ ' は Li2-b モデルで最小, Li2-d モデルで最大になっており，これらのモデル間での差は 12 であった。 それぞれのモデルにおいて二重結合酸素 $\mathrm{O} 2$, 非架橋酸素 $\mathrm{O} 3$ について見てみると, 結合距離 $r(\mathrm{P} 1-02)$, $r(\mathrm{P} 1-\mathrm{O} 3)$ 及び $r(\mathrm{Li1}-\mathrm{O} 2), r(\mathrm{Li1}-\mathrm{O} 3)$ は1.5 pm 以内でよく 一致した。 また, 結合角 $\angle \mathrm{Li} 1-\mathrm{O} 2-\mathrm{P} 1, \angle \mathrm{Li} 1-\mathrm{O} 3-\mathrm{P} 1$ \& $1^{\circ}$ 以 内で一致した．同様に表 1 から，計算したモデルの 02,03 の 電荷は比較的良く一致することが分かる．また，01 の電荷は O2, O3 に比べてモデルに大きく依存し，0.05程度の違いが生 じた.

表 1 に示した O1s 軌道エネルギーをエネルギー準位図とし

Table 1. Optimized Structures, Mulliken Charge of Oxygen Atoms and O1s Orbital Energy Values of Four Models Containing Two $\mathrm{PO}_{4}$ Units (see Fig. 1)

\begin{tabular}{|c|c|c|c|c|}
\hline & $\mathrm{Li} 2-\mathrm{a}$ & Li2-b & Li2-c & Li2-d \\
\hline \multicolumn{5}{|c|}{ Interatomic Distance / pm } \\
\hline P1-O1 & 163.3 & 163.2 & 163.5 & 162.8 \\
\hline $\mathrm{P} 1-\mathrm{O} 2$ & 151.4 & 151.8 & 152.1 & 151.6 \\
\hline $\mathrm{P} 1-\mathrm{O} 3$ & 152.4 & 152.3 & 152.1 & 152.1 \\
\hline $\mathrm{Li} 1-\mathrm{O} 2$ & 194.2 & 194.7 & 194.3 & 194.4 \\
\hline Li1-O3 & 195.5 & 195.0 & 194.3 & 194.9 \\
\hline \multicolumn{5}{|c|}{ Bond Angle / deg. } \\
\hline P1-O1-P1' & 139.97 & 130.79 & 134.18 & 142.94 \\
\hline $\mathrm{O} 2-\mathrm{P} 1-\mathrm{O} 1$ & 114.37 & 109.92 & 110.70 & 110.75 \\
\hline O3-P1-O1 & 108.34 & 111.44 & 108.13 & 109.58 \\
\hline Li1-O2-P1 & 85.42 & 85.05 & 85.38 & 85.27 \\
\hline Li1-O3-P1 & 84.72 & 84.79 & 85.38 & 84.93 \\
\hline \multicolumn{5}{|c|}{ Mulliken Charge } \\
\hline 01 & -0.700 & -0.652 & -0.667 & -0.657 \\
\hline $\mathrm{O} 2$ & -0.768 & -0.764 & -0.792 & -0.770 \\
\hline $\mathrm{O} 3$ & -0.775 & -0.789 & -0.774 & -0.778 \\
\hline $\mathrm{O} 2^{\prime}$ & & -0.784 & & \\
\hline $\mathrm{O} 3^{\prime}$ & & -0.772 & & \\
\hline \multicolumn{5}{|c|}{ O1s Orbital Energy / eV } \\
\hline $\mathrm{O} 1$ & -521.06 & -521.12 & -521.06 & -521.08 \\
\hline $\mathrm{O} 2$ & -519.40 & -519.54 & -519.40 & -519.45 \\
\hline $\mathrm{O} 3$ & -519.38 & -519.62 & -519.35 & -519.46 \\
\hline $\mathrm{O} 2^{\prime}$ & & -519.35 & & \\
\hline O3' & & -519.40 & & \\
\hline
\end{tabular}

て図 4 に示した．この図より，架橋酸素である 01 に帰属され る軌道エネルギーはモデルによらずほぼ一致し，O2, $\mathrm{O} 3$ と比 べて深い位置に見られた，O2，03，(02'，O3'）の軌道エネル ギーもモデルによらずほぼ同じレベルになった.

\section{2 異なるサイズのクラスター}

クラスターサイズを変化させたモデル Li2-a, Li4, Li5 の結果 を表 2 に示した．クラスターサイズの増加に従って，結合距離 $r(\mathrm{P} 1-\mathrm{O} 1), r(\mathrm{Li1}-\mathrm{O} 2), r(\mathrm{Li} 1-\mathrm{O} 3)$ は短くなる傾向が見られ， 結合距離 $r(\mathrm{P} 1-\mathrm{O} 2), r(\mathrm{P} 1-03)$ 及び結合角はサイズによらず 一致した。 また，それぞれのモデルについて二重結合酸素 $\mathrm{O} 2$ ，非架橋酸素 $\mathrm{O} 3$ に注目した場合, 結合距離 $r(\mathrm{Li} 1-\mathrm{O} 2)$, $r(\mathrm{Li} 1-\mathrm{O} 3)$ 及び $r(\mathrm{P} 1-\mathrm{O} 2), r(\mathrm{P} 1-\mathrm{O} 3)$ は $1.5 \mathrm{pm}$ 以内でよく一 致した。また，結合角 $\angle \mathrm{Li} 1-\mathrm{O} 2-\mathrm{P} 1$ と $\angle \mathrm{Li} 1-\mathrm{O} 3-\mathrm{P} 1$ \& $1^{\circ}$ 以 内で一致した。 01 のマリケン電荷については, 0.04異なって いるが，クラスターサイズに依存した系統的な変化は見られな かった. クラスターサイズを変化させたすべてのモデルにおい て 02,03 の電荷はほぼ同じ值を示した。 また，各モデルごと に比較した場合，O2 と 03 の電荷はよく一致した.

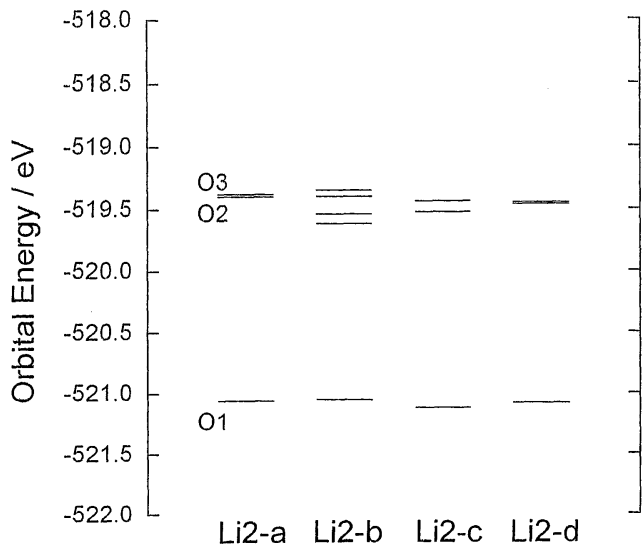

Fig. 4. O1s orbital energy levels of Li2-a, Li2-b, Li2-c and Li2-d models.

Table 2. Optimized Strucures, Mulliken Charge of Oxygen Atoms and O1s Orbital Energy Values of Models Containing Different Number of $\mathrm{PO}_{4}$ Units (see Fig. 2)

\begin{tabular}{|c|c|c|c|}
\hline & $\mathrm{Li} 2-\mathrm{a}$ & $\mathrm{Li} 4$ & $\mathrm{Li} 5$ \\
\hline \multicolumn{4}{|c|}{ Interatomic Distance /pm } \\
\hline P1-O1 & 163.3 & 161.6 & 161.4 \\
\hline $\mathrm{P} 1-\mathrm{O} 2$ & 151.4 & 151.6 & 151.8 \\
\hline $\mathrm{P} 1-\mathrm{O} 3$ & 152.4 & 151.9 & 152.3 \\
\hline $\mathrm{Li1}-\mathrm{O} 2$ & 194.2 & 193.5 & 192.5 \\
\hline Li1-O3 & 195.5 & 194.4 & 191.5 \\
\hline \multicolumn{4}{|c|}{ Bond Angle / deg. } \\
\hline P1-O1-P1' & 139.97 & 143.56 & 142.92 \\
\hline O2-P1-O1 & 114.37 & 114.62 & 114.88 \\
\hline O3-P1-O1 & 108.34 & 110.25 & 105.83 \\
\hline Li1-O2-P1 & 85.42 & 85.51 & 85.71 \\
\hline Li1-O3-P1 & 84.72 & 85.10 & 85.90 \\
\hline \multicolumn{4}{|c|}{ Mulliken Charge } \\
\hline $\mathrm{O} 1$ & -0.700 & -0.659 & -0.660 \\
\hline $\mathrm{O} 2$ & -0.768 & -0.772 & -0.777 \\
\hline $\mathrm{O} 3$ & -0.775 & -0.761 & -0.768 \\
\hline \multicolumn{4}{|c|}{ O1s Orbital Energy / eV } \\
\hline 01 & -521.06 & -521.05 & -521.11 \\
\hline O1' & & & -520.97 \\
\hline $\mathrm{O} 2$ & -519.40 & -519.33 & -519.30 \\
\hline $\mathrm{O} 3$ & -519.38 & -519.23 & -518.99 \\
\hline
\end{tabular}


これらのクラスターモデルの O 1s 軌道エネルギーをエネル ギー準位図として図 5 に示した。計算された軌道エネルギーは 01, (O1'), 02, O3 の順に浅くなった. Li5 モデルに関して, 隣 接した原子との結合において 01 と $1^{\prime}$ は結合距離及び結合角 は等価であるにも関わらず，01s 軌道エネルギーは0.14 eV の 差が存在した。しかしながら，この差はXPS の測定精度を考 慮すると小さく，01(O1') の軌道エネルギーはサイズによら ずほぼ一定と見なすことができる．あた，02 の軌道エネル ギーもサイズによらず，ほぼ一定になった．０3 の軌道エネル ギーはサイズの増加に伴って，より浅いエネルギーにシフトし た.このため, $\mathrm{O} 2$ と $\mathrm{O} 3$ のエネルギー差はクラスターサイズ が大きくなるにつれて大きくなり，Li5 モデルで $0.31 \mathrm{eV} に$ なった。

\section{3 鎖内結合の変化}

$\mathrm{PO}_{4}$ ユニットを 5 個有するグループLi5-A, Li5-B のモデル を対象として，鎖内のねじれによって生じる不規則性が与える 影響を検討した結果を表 3 に示した．鎖内の面角の変化が大き くなり，周囲の $\mathrm{PO}_{4}$ ユニットとの位置関係が変化したどのモ デルに拈いても，01 とO1'の電荷はほぼ一致した。 また，モ デルごとに比較した場合，構造的にはほぼ等価になっている $\mathrm{O} 2$ と $\mathrm{O} 3$ の電荷は, よく一致していた.

図 6 にこれらのモデルの $01 \mathrm{~s}$ 軌道エネルギーをエネルギー 準位図として示した．これらのモデルの軌道エネルギーは 01 , O1'，O2，O3 の順に浅いエネルギーレベルになった．１と O1' の軌道エネルギーには最大で $0.18 \mathrm{eV}$ の差が存在するが, どのモデルもそのエネルギー差はほぼ一定であった。 O2, $\mathrm{O} 3$ のエネルギー差はクラスターモデルによって異なっており，そ の差の平均はおおよそ0.4 eV となった。特に, Li5-A グルー

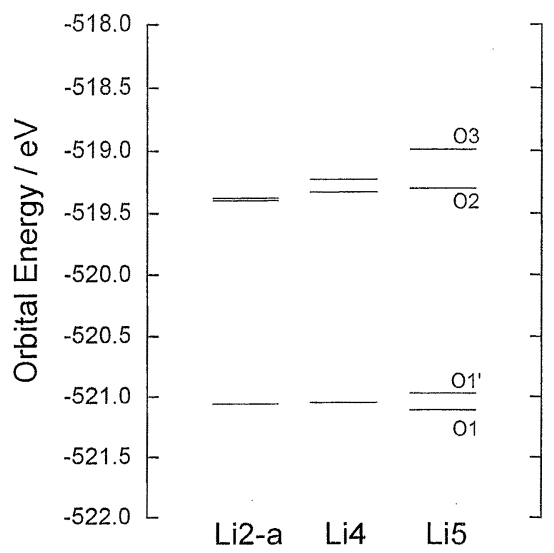

Fig. 5. O1s orbital energy levels of Li2-a, Li4 and Li5 models.
プの $90^{\circ}$ 回転モデル, Li5-B グループの-60ำ回転モデルでエ ネルギー差は最大になっており，どちらも $0.51 \mathrm{eV}$ となった. また，Li5-A グループの $60^{\circ}$ 回転モデルにおいてもエネルギー 差は大きく， $0.41 \mathrm{eV}$ を有した。

図 7 にこれらのモデルに関して計算された系の全エネルギー を示した．計算される全エネルギーは深いほど系が安定してい ることを表し，本計算で用いたように同種，同数の原子から構 成される場合に扔いて，全エネルギーの大小がモデルの相対的 な安定性を示している. 図より, Li5-A グループの60 回転し たモデルの全エネルギーが最も小さく, 安定であり, Li5-B グ ループの $60^{\circ}$ 回転モデルが最も不安定であることが分かる。ま

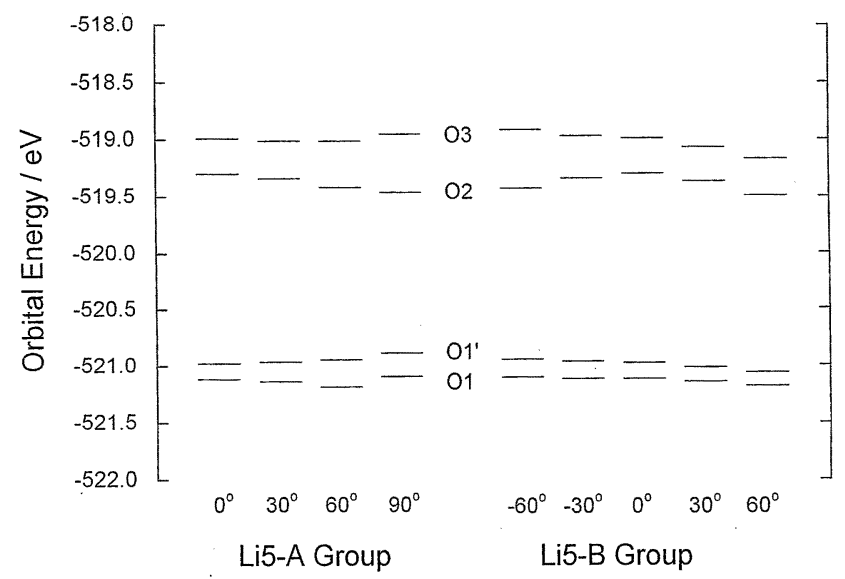

Fig. 6. O1s orbital energy levels of models in Li5-A and Li5-B groups.

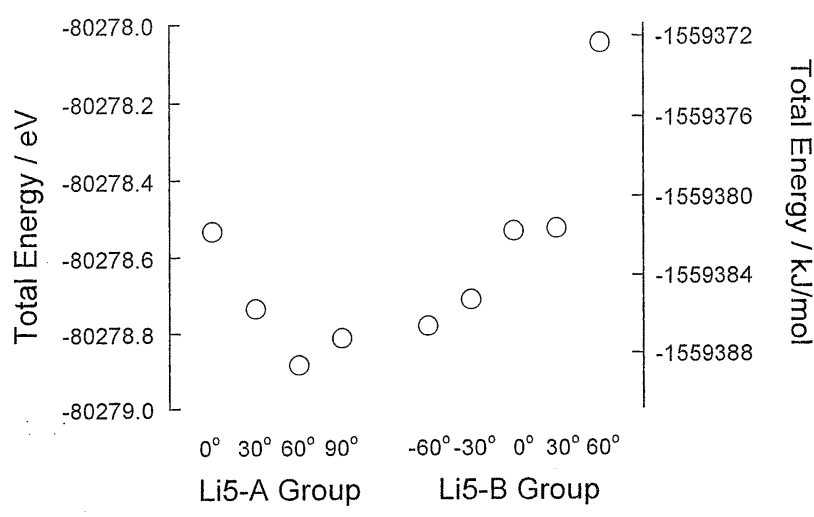

Fig. 7. Total energy values of models in Li5-A and Li5-B groups. Left $y$-axis represents $\mathrm{eV}$ scale and right $y$-axis represents $\mathrm{kJ} / \mathrm{mol}$ scale.

Table 3. List of Mulliken Charge of Oxygen Atoms and O1s Orbital Energy Values of Models Containing Five $\mathrm{PO}_{4}$ Units (see Fig. 3)

\begin{tabular}{cccccccccc}
\hline \multicolumn{3}{c}{ Li5-A Group } & \multicolumn{7}{c}{ Li5-B Group } \\
rotaion angle / deg. & 0 & 30 & 60 & 90 & -60 & -30 & 0 & 30 & 60 \\
\hline Mulliken Charge & & & & & & & & & \\
O1 & -0.660 & -0.659 & -0.658 & -0.661 & -0.667 & -0.664 & -0.660 & -0.662 & -0.667 \\
O1' & -0.660 & -0.655 & -0.675 & -0.677 & -0.669 & -0.665 & -0.660 & -0.659 & -0.663 \\
O2 & -0.777 & -0.783 & -0.788 & -0.778 & -0.778 & -0.781 & -0.777 & -0.784 & -0.795 \\
O3 & -0.768 & -0.774 & -0.786 & -0.789 & -0.802 & -0.782 & -0.768 & -0.767 & -0.768 \\
O1s Orbital Energy $/ e V$ & & & & & & & & & \\
O1 & -521.11 & -521.14 & -521.18 & -521.09 & -521.10 & -521.11 & -521.11 & -521.14 & -521.18 \\
O1' & -520.97 & -520.96 & -520.94 & -520.88 & -520.94 & -520.96 & -520.97 & -521.02 & -521.06 \\
O2 & -519.30 & -519.34 & -519.42 & -519.46 & -519.42 & -519.33 & -519.30 & -519.36 & -519.49 \\
O3 & -518.99 & -519.01 & -519.01 & -518.95 & -518.91 & -518.97 & -518.99 & -519.06 & -519.34 \\
\hline
\end{tabular}


た, Li5-Aグループの $90^{\circ}$ 回転モデルやLi5-B グループの - $60^{\circ}$ 回転モデルも計算したこれらのモデルの中では安定であ るといえる.

\section{1 クラスターサイズ}

\section{4. 考察}

$\mathrm{PO}_{4}$ の個数を変化させた場合のモデル Li2-a, Li4, Li5 を用 いて，鎖長の影響に関して考察した.これらのモデルの最適化 構造に関して, 実測のリチウムメタリン酸塩の構造パラメー ターと比較する．ガラスに関してはリンと架橋酸素及び非架橋 酸素との間の厳密な結合距離が報告されていないため, 局所構 造がより詳細に調べられている高温型 $\mathrm{LiPO}_{3}$ 結晶と比べてみ る. 高温型 $\mathrm{LiPO}_{3}$ 結晶における架橋酸素とリンの結合距離は 平均 $159.8 \mathrm{pm}$ であり, 非架橋酸素とリンの結合距離は平均 $148.1 \mathrm{pm}$ であった。 また， $\mathrm{Li}^{+}$イオンの局所構造に注目する と, リチウムの配位数は 4 であり, 非架橋酸素々の結合距離 は平均 $196.0 \mathrm{pm}$ と測定されている ${ }^{27)}$. 表 2 より本計算により 得られたクラスターモデル中の結合距離は，これらのすべての 結合距離に関して，5 pm 以内で一致していることが分かる. これらの一致は, 上記モデルにより局所構造はおおよそ再現で きていることを表している.

最む小さい Li2-a モデルにおいて O2, O3 に注目した場合は, 表 2 及び図 5 の結果よりこれらの酸素が構造的に等価であり O1s 軌道エネルギーのエネルギー差も $0.02 \mathrm{eV}$ と非常に小さい ことが分かり，Uchino とOgataによって行われた $\mathrm{PO}_{4}$ ユニッ 卜を 2 個含む $\mathrm{Na}_{2} \mathrm{O}-\mathrm{P}_{2} \mathrm{O}_{5}$ 系クラスターの計算結果 ${ }^{14)}$ と良く一 致した．クラスターサイズを大きくすると，02，03 は表 2 上 り構造的には等価であるといえるが，図 5 より O1s 軌道エネ ルギーのエネルギー差は影響を受け, 増加することが分かる.

最もクラスターサイズの大きな Li5 モデルにおける $\mathrm{O} 1 \mathrm{~s}$ 軌道 エネルギーの差は $0.31 \mathrm{eV}$ となっており， Brücknerによる ピーク分離によって得られた非架橋酸素と二重結合酸素に帰属 される結合エネルギーの差と近い值を示している.クラスター サイズの効果は局所構造の違いには表れなかったものの, 電子 状態に影響を与えていることになる.クラスターサイズが増加 するに従って, 終端水素の影響は小さくなるため, 大きなクラ スターサイズを有するモデルはより固体中の状態に近くなって いるものと考えられる．また，O2，O3 のエネルギー差がクラ スターサイズに依存して大きくなるのは，現実の固体状態に近 くなるにつれて, 隣接する原子からの影響の及ではなく, 周囲 に存在する他の元素からの影響を受けるためとも考えられる. そこで，以下ではより固体状態に近い 5 個の $\mathrm{PO}_{4}$ ユニットを 含んだモデルについて，ユニット間の結合状態を変化させるこ とによって酸素の電子状態がどのように影響を受けるのかにつ いて考察していく.

\section{2 鎖内結合の変化}

図 7 に示されているモデルごとの全エネルギーの差は, ガ ラス中に存在する鎖内に生じる鎖状構造の不規則性の一例と考 えることができる.このエネルギー差がどの程度の大きさなの かは, 規則的に配列した結晶と不規則構造を取っているガラス を比較することによって明らかになる．結晶とガラスの結合状 態の違いによる安定性は実測の生成エンタルピーを用いること によって評価できる、ここではリチウムメタリン酸塩の結晶と ガラスに関して, $\mathrm{Li}_{2} \mathrm{O}$ と $\mathrm{P}_{2} \mathrm{O}_{5}$ からの生成する際の生成熱を用 いて比較する。これをで, 結晶及びガラスを塩酸を用いて溶解 した時の溶解熱からこれらの生成熱が求められている28).こ の結果, 結晶は $-211.3 \pm 3.8 \mathrm{~kJ} / \mathrm{mol}$ であり, ガラスは -195.4 $\pm 3.8 \mathrm{~kJ} / \mathrm{mol}$ であることから，これらの差は $15.9 \mathrm{~kJ} / \mathrm{mol}$ であ る. 不規則性を有するガラスに比べて, 結晶は配列することに よってその鎖内及び鎖間の結合状態が変化し安定になる．結晶 とガラスの生成熱の差はこの結合状態の安定性がどの程度異 なっているかを表している.

図 7 より $\mathrm{LiPO}_{4}$ ユニット $1 \mathrm{~mol}$ 当たりのエネルギー差は最 も安定なモデル（Li5-A グループの60 回転モデル）上不安定 なモデル（Li5-B グループの60 $60^{\circ}$ 回転モデル）の間で約 16 $\mathrm{kJ} / \mathrm{mol}$ になることが分かる.このエネルギー差は鎖内の結合 状態の変化しか考えていないため, 生成熱の差によって表され たものとは厳密には異なっている。しかしながら， $1000^{\circ} \mathrm{C}$ 以 上の高温でのガラスの溶融生成過程を考えると, $1000^{\circ} \mathrm{C}$ にお ける熱エネルギーは $R T \simeq 8.3 \mathrm{~kJ} / \mathrm{mol}$ である. このエネルギー は鎖内の面角を変化させる程度の運動エネルギーであることか ら, 鎖内のねじれによる結合状態の変化は実際のガラス作製過 程において起こりうると考えられる。すなわち，鎖内のねじれ はガラス中に存在しうる不規則性の一つであるといえる.

$\mathrm{PO}_{4}$ ユニットを 5 個含んだモデルにおいて，02 と $\mathrm{O} 3$ の O1s 軌道エネルギーの差は常に一定ではなく, 面角の変化に 伴って変化することが図 6 から分かる. そのエネルギー差は， Li5-A グループの $90^{\circ}$ 回転及び $60^{\circ}$ 回転モデルや Li5-B グルー プのー $60^{\circ}$ 回転モデルで大きくなっている. 図 7 による全エネ ルギーの比較から，これらのモデルはエネルギー的に安定であ ることが分かる.

$\mathrm{PO}_{4}$ ユニット間の結合位置が与える影響に関して, $\mathrm{PO}_{4}$ ユ ニットを 2 個含むモデルの中で Li2-b 及び Li2-c モデルの結合 角 $\angle \mathrm{P} 1-\mathrm{O} 1-\mathrm{P} 1^{\prime}$ は Li2-a 及び Li2-d モデルと比較すると $10^{\circ}$ 程 度小さいことが表1より分かり，この大きさは高温型 $\mathrm{LiPO}_{3}$ 結 晶の $\angle \mathrm{P} 1-01-\mathrm{P} 1^{\prime}$ に相当する角の大きさ（平均で $\left.133.9^{\circ} 27\right)$ ) にほほ一致している．Li2-b 及びLi2-c モデルにおいて，隣接 している 2 個の $\mathrm{PO}_{4}$ ユニット内にあるリチウムイオン同士や 末端酸素同士の距離は, 高温型 $\mathrm{LiPO}_{3}$ 結晶と同様に離れてお り, これらの反発は小さくなっていることを考慮すると, 同種 原子の反発が系の安定性に大きく影響していると考えられる. 上述した $\mathrm{PO}_{4}$ ユニットを 5 個含むモデルにおいても隣接する $\mathrm{PO}_{4}$ ユニット間のリチウムイオン同士や末端酸素同士が離れ ており, 面角を変化させることによってクラスターモデル中に 生じた鎖内のねじれが $\mathrm{O} 2$ 及び $\mathrm{O} 3$ の電子状態に大きな影響を 与えるといえる.このように隣接する $\mathrm{PO}_{4}$ ユニット間の位置 関係によってリチウムイオン同士または末端酸素同士の反発の 大きさが変化することから, 鎖内に作られる不規則性には末端 酸素, 修飾イオンが重要な役割を持つとともに, 末端酸素自身 の電子状態に影響を与えることが分かる.

$\mathrm{PO}_{4}$ ユニットを 5 個有するモデルにおいて, エネルギー的 に安定になった Li5-A グループの60 回転モデルの場合, O2, $\mathrm{O} 3$ の軌道エネルギー差は $0.41 \mathrm{eV}$ となった. また, さまざま な結合状態を表している他のモデルにおいても軌道エネルギー の差は存在しており, 02 と03 の軌道エネルギーの差は平均 で約 $0.4 \mathrm{eV}$ となった. 表 2 の Li5 モデルの結果から, 02 と O3 は $\mathrm{Li}^{+}$イオンに対して等価な位置に結合していることが分 かる.このように, 構造的には等価な場合であっても, 周囲に 存在する原子によって 01s 結合エネルギーの目安となる O $1 \mathrm{~s}$ 軌道エネルギーに違いが生じることが分かる.これらのモデル について計算された 02 と03 のエネルギー的な違いは電子状 態に違いが存在することを表している.

\section{3 酸素の電荷と化学結合状態}

これまで, 内殼軌道の結合エネルギーのケミカルシフトを検 
討するうえで, 結合エネルギーが表している電子状態として電 荷の概念との対応関係が検討されてきた8) 11). 本計算によっ て求められたマリケン電荷と $01 \mathrm{~s}$ 軌道エネルギーとの関係を 図 8 に示す. 負電荷の増加に伴って軌道エネルギーがより浅い エネルギーレベルにケミカルシフトした．この関係はこれをで 報告されている負電荷の増加に伴って結合エネルギーが低エネ

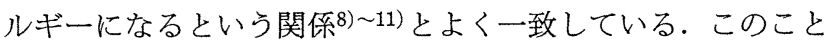
は電荷が 01s 軌道エネルギーを反映した值になって抢り， XPS で測定される O1s 光電子スペクトルを考えるうえでも重 要な情報を与えてくれることを示唆している.

計算された $\mathrm{O} 2$ 及び $\mathrm{O} 3$ の電荷は，各モデルごとでほぼ等し いことが表 1 , 表 2 , 表 3 から分かる.この結果から $\mathrm{Li}^{+}$イオ ンがこれらの酸素の両方とほぼ等価な結合状態で結合している ことが予測できる.すなわち，それぞれの酸素がリンとの間で はほほ1.5重結合に近い結合を取っていると考えられる．これ らの結果は, 種々のリン酸塩に関して価電子带の電子密度分布 を tight-binding 法によって計算した結果 ${ }^{29}$ によって裏付けら れる.この計算では, 非架橋酸素の $2 \mathrm{p} \pi$ 軌道とリンの $3 \mathrm{~d}$ 軌道 が価電子帯の上部を占めていることが表されており, リンと酸 素の間で $\pi$ 結合を形成していることを表しているといえる. このように考えると, XPS で区別される二つのピークは明確 に異なる結合状態を持った二重結合酸素と非架橋酸素なのでは なく，構造的には等価なものであると考えられる.

以上のように，分子軌道計算よりリチウムメタリン酸塩ガラ ス中には, 非架橋酸素と二重結合酸素として, 構造的にも O1s 結合エネルギーについても区別をつけることができない酸 素が存在することが示された．しかしながら，それぞれの末端 酸素の $01 \mathrm{~s}$ 軌道エネルギーは $0.4 \mathrm{eV}$ 程度異なって計算された. このエネルギー差は検出可能であると考えられるが，構造的に 等価であること及びクラスターサイズが大きくなるにつれてエ ネルギー差が増加したことを考慮すると，ガラス特有の不規則 性に起因する，隣接する $\mathrm{PO}_{4}$ ユニットに存在する原子との位 置関係，すなわち周囲の結合状態の違いによって生じるものと 解釈できる.

本計算で用いたモデルはメタリン酸塩特有の無限遠の鎖状構 造の一部を取り出したものとして位置づけており，これらのモ デルの鎖状構造の変化を検討することで，ガラス中の網目構造 の不規則性が酸素の電子状態に与える影響を推察できた. しか しながら，実際のガラス中での構造と計算で用いたモデルの対

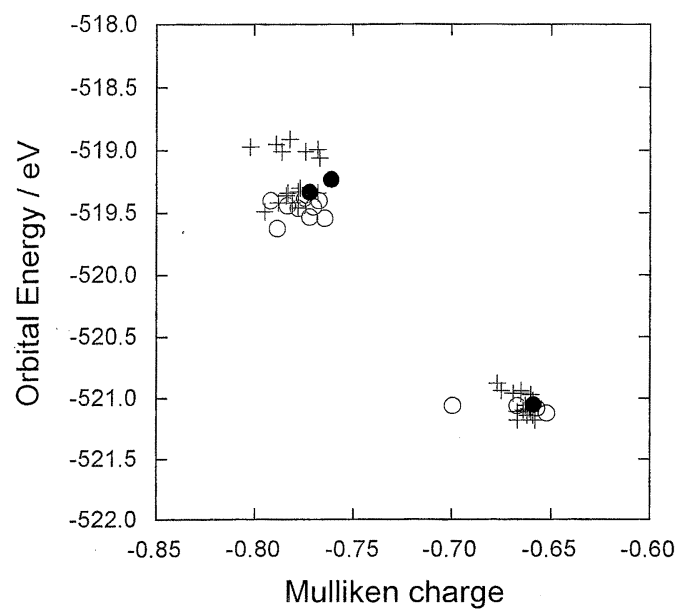

Fig. 8. Plot of O1s orbital energy values versus Mulliken charges on the oxygen atoms. $\bigcirc \mathrm{Li} 2-\mathrm{a}, \mathrm{Li} 2-\mathrm{b}, \mathrm{Li} 2-\mathrm{c}$ and $\mathrm{Li} 2-\mathrm{d}$ models, - Li4 model and + Li5-A and Li5-B groups.
応という観点において, 厳密にガラス中の不規則構造を議論し ていく際には，以下の 2 点に関する検討を行うことが重要で あると考えている.

第 1 点目は， $\mathrm{Li}^{+}$イオンの配位状態である．計算結果では $\mathrm{Li}^{+}$イオンは二つの酸素に配位したが，結晶中の配位状態27)を 考慮すると, ガラス中での配位数も 2 より大きくなっている ものと予想され，実際，中性子線回折の結果から $4.0 \pm 0.4$ であ ることが報告されている ${ }^{30)}$. 他の鎖から受ける影響などを考 慮した計算を行うことによって，固体中の配位数により近づけ ることができるものと思われる.

第 2 点目としては，鎖状構造のモデルにおける束縛条件が考 えられる. 今回用いたモデルは無限遠の鎖の一部であるが，構 造最適化において多くの束縛条件を用いており，実際のガラス 中には計算で用いたモデル以外の鎖状構造も多く存在してい る.

上記の 2 点を満たすモデルを構築することによって, 鎖状 構造の影響だけでなく, より複雑な実際のガラス系に近い不規 則構造を再現できるものと考えている.

\section{5. 結 論}

リン酸塩ガラスの XPS で得られる O1s 光電子スペクトルの 低エネルギー側のピークを非架橋酸素と二重結合酸素に分離し て㷌属することの妥当性を検討するため, リチウムメタリン酸 塩鎖状クラスターに関して, 鎖長や鎖内結合のねじれが酸素の 電子状態に与える影響について密度沉関数法を用いた分子軌道 計算を行った.

(1) 1 個の $\mathrm{PO}_{4}$ ユニット当たりに 1 個の $\mathrm{Li}^{+}$イオンを有す る $\mathrm{PO}_{4}$ ユニットが $2,4,5$ 個鎖状に結合したモデルにおいて, 計算を行う際の初期構造における非架橋酸素と二重結合酸素は $\mathrm{Li}^{+}$イオンの周囲で鎖長や鎖内結合のねじれと関係なく，いず れの場合においても結合距離, 結合角は等価であると判断され た.

（2）鎖状クラスター中の鎖内結合のねじれを変化させるこ とによって, 隣接原子間の化学結合状態の変化がない場合でも 末端酸素の $01 \mathrm{~s}$ 軌道エネルギーは $0.4 \mathrm{eV}$ 程度のエネルギー差 が生じることが明らかになった.このようなエネルギーの差は 不規則性に起因する周囲に存在する原子との相互作用の変化に よって生じるものであると考えられた. したがって, XPSで 測定される $01 \mathrm{~s}$ 光電子スペクトルの低結合エネルギー側の ピークは非架橋酸素, 二重結合酸素といった異なる状態の酸素 に分けて帰属するよりは, 分布を持った共鳴状態として一つの ピークになるものと解釈する方が妥当である.

\section{文献}

1) R. Brückner, H.-U. Chun, H. Goretzki and M. Sammet, J. Non-Cryst. Solids, 42, 49-60 (1980).

2) S. Matsumoto, T. Nanba and Y. Miura, J. Ceram. Soc. Japan, 106, 415-21 (1998) [in Japanese].

3) Y. Kaneko, H. Nakamura, M. Yamane and Y. Suginohara, $J$. Ceram. Soc. Japan (Yogyo-Kyokai-Shi), 90, 557-62 (1982) [in Japanese].

4) R. Gresch, W. Müller-Warmuth and H. Dutz, J. Non-Cryst. Solids, 34, 127-36 (1979).

5) Y. Kaneko, J. Ceram. Soc. Japan (Yogyo-Kyokai-Shi), 88, 497-99 (1980).

6) H. Segawa, T. Yano, S. Shibata and M. Yamane, Proc. 18 th International Congress on Glass, D8, Am. Ceram. Soc., San Francisco (1998) pp. 22-26.

7) J. J. Hudgens and S. W. Martin, J. Am. Ceram. Soc., 76, 1691-96 (1993).

8) K. Siegbahn, C. Nordling, G. Johansson, J. Hedman, P. F. 
Hedén, K. Hamrin, U. Gelius, T. Bergmark, L. O. Werme, R. Manne and Y. Baer, "ESCA Applied to Free Molecules," North-Holland, Amsterdam (1969).

9) R. Nordberg, R. G. Albridge, T. Bergmark, U. Ericson, J. Hedman, C. Nordling, K. Siegbahn and B. J. Lindberg, Arkiv. Kemi., 28, 257-78 (1967).

10) C. Sleigh, A. P. Pijpers, A. Jaspers, B. Coussens and R. J. Meier, J. Electron Spectrosc. Relat. Phenom., 77, 41-57 (1996).

11) B. Folkesson and R. Larsson, J. Electron Spectrosc. Relat. Phenom., 50, 267-76 (1990).

12) D. P. Chong, Chem. Phys. Lett., 232, 486-90 (1995).

13) T. Uchino and Y. Ogata, J. Non-Cryst. Solids, 191, 56-70 (1995).

14) T. Uchino and Y. Ogata, J. Non-Cryst. Solids, 181, 175-88 (1995)

15) M. Tatsumisago, Y. Kowada and T. Minami, Phys. Chem. Glasses, 29, 63-66 (1988).

16) E. Thilo and H. Grunze, Z. Anorg. Allg. Chem., 281, 262-83 (1955).

17) J. C. Grenier and A. Durif, Z. Kristallogr., 137, 10-16 (1973).

18) P. Hohenberg and W. Kohn, Phys. Rev., 136, 864-71 (1964).

19) M. J. Frisch, G. W. Trucks, H. Schlegel, P. M. W. Gill, B. G. Johnson, M. A. Robb, J. R. Cheeseman, T. A. Keith, G. A. Petersson, J. A. Montgomery, K. Raghavachari, M. A. AlLaham, V. G. Zakrezewski, J. V. Ortiz, J. B. Foresman, J.
Cioslowski, B. B. Stefanov, A. Nanayakkara, M. Challacombe, C. Y. Peng, P. Y. Ayala, W. Chen, M. W. Wong, J. L. Andres, E. S. Replogle, R. Gomperts, R. L. Martin, D. J. Fox, J. S. Binkley, D. J. Defrees, J. Baker, J. P. Stewart, M. Head-Gordon, C. Gonzalez and J. A. Pople, “Gaussian 94 Revision D," Gaussian, Inc., Pittsburgh, PA (1995).

20) A. D. Becke, J. Chem. Phys., 98, 5648-52 (1993).

21) C. Lee, W. Yang and R. G. Parr, Phys. Rev. B, 37, 785-89 (1988).

22) S. H. Vosko, L. Wilk and M. Nusair, Can. J. Phys., 58, 120011 (1980).

23) A. D. Becke, Phys. Rev. A, 38, 3098-100 (1988).

24) Unichem Chemistry Codes APG-5505 3.0, Cray Research, Inc.

25) T. A. Koopmans, Physica, 1, 104 (1933).

26) J. F. Janak, Phys. Rev. B, 18, 7165-68 (1978).

27) J. C. Guitel and I. Tordjman, Acta. Cryst., B32, 2960-66 (1976).

28) T. R. Meadowcroft and F. D. Richardson, Trans. Faraday Soc., 59, 1564-71 (1963).

29) A. Le Beuze, R. Lissillour, A. Quemerais, D. Agliz, R. Marchand and H. Chermette, Phys. Rev. B, 39, 11055-65 (1989).

30) J. Swenson, A. Matic, A. Brodin, L. Börjesson and W. S. Howells, Phys. Rev. B, 58, 11331-37 (1998). 